\title{
ПОСТМОДЕРНІСТСЬКИЙ ВИМІР РОМАНІВ ФІЛІПА РОТА
}

\author{
Вероніка Лісевич \\ Магістр філології, аспірант, \\ Кафедра германських мов і зарубіжної літератури, \\ Кам’янець-Подільський національний університет імені Івана Огієнка (УКРАЇНА), \\ 32300, м. Кам'янець-Подільський, вул. Івана Огієнка, 61, \\ e-mail: nika199574@gmail.com
}

\section{PЕФЕРАТ}

Статтю присвячено дослідженню особливостей втілення постмодерністської парадигми в романах Філіпа Рота. Метою статті є з'ясування співвідношення основних параметрів постмодерністської концепції $з$ жанрово-стильовою і поетико-наративною специфікою творчості Ф. Рота. Дослідницька методика базується на використанні історико-літературного, структурно-функціонального, наратологічного методів та принципів інтертекстуального аналізу. У результаті дослідження виявлено, що ознаки постмодернізму простежуються у більшості творів Ф. Рота, однак попри численні експерименти 3 реальністю і наративом, кращі романи письменника (як-от е. g. «Людське тавро») засвідчують еволюцію до «воскресіння суб'єкта«, відновлення повноцінного людського характеру замість концептуалізації розщепленого «Я» і дегуманізованої особистості. Наукова новизна дослідження полягає у виявленні трансформації концепту «епістемологічна невизначеність» та його складників у творчості Філіпа Рота: відчуття невиправності існування, неможливості осягнення глибинних меж людської сутності залишається актуальним, але набуває ознак екзистенціального запитування. Матеріал статті може бути використаний науковцями в процесі подальшого вивчення еволюції постмодернізму в новітній літературі, а також у процесі виконання кваліфікаційних робіт у закладах вищої освіти.

Ключові слова: Ф. Рот, постмодернізм, епістемологічна невизначеність, реальність і фікційність, жанр, стиль.

\section{THE POSTMODERN DIMENSION OF PHILIP ROTH'S NOVELS}

\section{Veronika Lisevych}

\author{
Master of Philology, Postgraduate, \\ Foreign Literature and German Languages Department, \\ Kamianets-Podilskyi National Ivan Ohiienko University (UKRAINE), \\ 32300, Kamianets-Podilskyi, 61, Ivan Ohiienko str., \\ e-mail: nika199574@gmail.com
}

\begin{abstract}
The article is dedicated to the study of the features of the postmodern paradigm in Philip Roth's novels. The aim of the article is to find out the correlation of the basic parameters of the postmodern concept with the genre-style and poetic-narrative specificity of F. Roth's works. Historical and literary, cultural-historical, structural, narratological and intertextual methods are used for the research. The results of the research show that signs of postmodernism can be traced in most of Roth's works, however, despite numerous experiments with reality and narrative, the best novels of the writer (e. g. The Human Stain) witness evolution to the «resurrection of the subject», the restoration of a full-fledged human character instead of the conceptualization of a split «I» and dehumanized person. Scientific novelty of the article lies in the fact that the concept of «epistemological uncertainty» and its components in the work of $\mathrm{Ph}$. Roth are transformed: the idea of inability to reach the deep limits of human essence remains relevant, but acquires signs of existential inquiry.
\end{abstract}

Key words: Ph. Roth, postmodernism, epistemological uncertainty, reality and fiction, genre, style. 
Творчість видатного американського письменника Філіпа Рота $є$ настільки розмаїтою й багатогранною, що не вписується в рамки будь-якої сучасної філософсько-естетичної чи теоретико-літературної концепції. Його називають то новим реалістом [3], то екзистенціалістом [6], то постмодерністом [2]. Віднесення письменника до постмодернізму проблематизується й через розмитість самого цього феномену. Не так давно газета «Лос-Анджелес Таймс» опублікувала список «взірцевих» постмодерністських творів [5], до яких зараховано, зокрема, Шекспірового «Гамлета», «Трістрама Шенді» Лоуренса Стерна і навіть «Червону літеру» Натаніеля Готторна. Цей список свідчить щонайменше про відсутність чітких критеріїв постмодернізму, але й водночас опосередковано підтверджує думку українського вченого Дмитра Затонського про те, що постмодернізм не власне історичний, а в першу чергу типологічний феномен, який оприявнює «апокаліптичність» людського світовідчуття в різні історичні епохи [12, с. 4-6]. Тим не менше є чимало солідних видань, в яких здійснюється спроба систематизувати ознаки постмодернізму. Одне 3 них «Енциклопедія постмодернізму», опублікована 2001 року за редакцією авторитетних фахівців Чарлза Е. Вінквіста та Віктора Е. Тейлора [1]. Спробуймо в основному за цією енциклопедією максимально концентровано викласти основні ознаки постмодерністської парадигми, 3 тим щоб потім верифікувати їх наявність у творах Ф. Рота.

Художньо-естетична концепція постмодернізму грунтується на ствердженні адогматизму й плюралістичності світобачення. Децентралізація і деканонізація, невизначеність і релятивізм щодо спроб раціоналізувати життя, «відкрити істину», змінити світ на краще обіймаються формулою «епістемологічна непевність» (1). Це - перша й засаднича ознака постмодернізму, з якої випливають усі інші: проблематизація «реальності» i симулякровий характер буття (2); проблематизація людини як предмета літератури і заміна його самою літературою (3); тотальна іронія і гра - 3 реальністю, наративом, читачем, попередніми текстами (4); радикальний перегляд традиційних художніх конвенцій, особливо щодо статусу автора, що перетворюється на «авторську маску»; жанру і стилю, контамінація різних їх різних елементів у колаж і пастиш (5).

«Епістемологічну непевність» Філіпа Рота демонструють практично всі його твори - від збірки «Прощавай, Колумбусе» (1959) до роману «Немезида» (2010), оскільки наратори й протагоністи незмінно стикаються 3 неможливістю чітко й остаточно сформулювати сутність життя і місця в ньому людини. Основним персонажем книг Рота $є$ письменник, і тому проблема «непевності» існування набуває формату неспроможності написати «правдиву історію», розклавши на полички характер і долю людини. Чи не найяскравіше така ситуація постає в романі «Людське тавро» (2000).

Розповідь у ньому ведеться головним чином від імені досвідченого, шістдесяти п’ятилітнього письменника Натана Цукермана, який уже знайомий читачам із декількох попередніх романів письменника. В аналізованому творі Натан Цукерман виступає здебільшого в ролі спостерігача, оскільки 
утаємничена життєва історія головного героя Коулмена Сілка, декана i професора античної словесності одного 3 коледжів у Новій Англії, розкривається в перспективі декількох нараторів, зокрема й у власній розповіді Коулмена Сілка.

I основний наратор, і головний герой твору безпосередньо причетні своєю життєвою і професійною діяльністю до літератури, що зумовлює високий ступінь тематизації феномену художньої творчості й численні рефлексії щодо співвідношення літератури і життя, проблем творчого процесу тощо.

Сюжетом твору є не тільки історія життя Коулмена Сілка, а й сам процес написання Натаном Цукерманом роману про цю людину. Відтак роман «Людське тавро» має типову для метатекстової літератури двопланову структуру, організовану за принципом «текст у тексті». При цьому авторську позицію виокремити досить важко, оскільки власне автор (Філіп Рот) розосереджує свої оцінки й характеристики між різними нараторами. Крім двох основних нараторів, у романі такі функції перебирають на себе такі персонажі, як Фауні Фарлі, Леслі Фарлі, Ернестина, й навіть героїня відносно самостійної сюжетної лінії роману французька інтелектуалка Дельфіна Ру. Це сприяє створенню багатопланової поліфонічної розповіді.

Натан Цукерман починає писати свій роман про Коулмена Сілка вже після його трагічної загибелі в автокатастрофі разом із останньою подругою його життя Фауні Фарлі. А безпосереднім імпульсом творчого процесу стає знайомство письменника із сестрою Коулмена Сілка Ернестиною. Від неї він дізнається про «гігантську таємницю» («gigantic secret») [11] колишнього декана, якого всі знали як єврея за походженням, а насправді він був із афроамериканської родини і з вісімнадцяти років приховував цей факт, намагаючись «стати господарем власного життя« («to become his own man») [11].

Частину інформації про Коулмена Сілка Натан Цукерман отримав від нього самого, частину - від його колег із коледжу, частину - від Ернестини. Однак, визнаючи Сілка «ненадійним наратором», особливо стосовно його життя до приходу в Афіна-коледж, письменник керується власною творчою інтуїцією і фантазією, не приховуючи цього від читача. Він постійно рефлексує над самим процесом написання роману й уподібнює життя персонажа до художнього тексту. Подумки звертаючись до свого товариша і героя своєї книжки, Натан Цукерман стверджує: «Of course you could not write the book. You'd written the book - the book was your life. Writing personally is exposing and concealing at the same time, but with you it could only be concealment and so it would never work. Your book was your life - and your art? Once you set the thing in motion, your art was being a white man. Being, in your brother's words, "more white than the whites". That was your singular act of invention: every day you woke up to be what you had made yourself...» [11].

Відкривши для себе таємницю Коулмена Сілка, наратор відчуває, що вона стала для нього нав'язливою ідеєю, і позбутися ï можна лише через творче осягнення, перетворення письменницької роботи на фікційний квест, в якому вигадка і реальність перестають бути протилежностями і стають органічним продовженням одне одного, сповнюючись неочікуваних парадоксів: «There is 
suddenly no such thing as a back road that doesn't lead headlong into your obsession...» [11].

Створюючи художню розповідь про життя Коулмена Сілка, Натан Цукерман приходить до висновку про неможливість розставити у ній всі крапки над «і» і сформулювати остаточний вердикт в історії свого героя: «Now that I knew everything, it was as though I knew nothing...» [11]. Отож уявлення наратора про життя персонажа (i про життя загалом) підкреслено проблематизуються, й оцінка характеру, життєвого вибору і драматичної долі головного героя мають у романі статус невизначеності, що цілком відповідає постмодерністському світобаченню.

Друга ознака постмодернізму, сформульована вище як проблематизація «реальності» і симулякровий характер буття, в романах Ф. Рота виявляється знову ж таки через співвідношення мистецтва і дійсності, фікційного й реального автора. Розглянемо ії на прикладі роману «Звільнений Цукерман» (1981, назва мовою оригіналу - «Zuckerman Unbound»). Він є другим твором із трилогії автора про письменника Натана Цукермана (після роману 1979 року «Письменник-привид»). Сюжетом його $€$ творча історія роману вигаданого Цукерманом письменника Гілберта Карновскі 3 однойменною назвою «Carnovsky». Сам такий сюжет уже $\epsilon$ типовим казусом симулякру: Рот вигадує Цукермана, Цукерман вигадує Карновскі, пише про нього роман, в якому є персонаж Алвін Пеплер, фанатичний шанувальник творчості Цукермана.

Написавши роман про у максимально відвертій, сповідальній інтонації, Цукерман опинився в ситуації, коли його персонаж і критиками, і звичайними читачами став сприйматися як alter ego автора, а жанровою домінантою роману вважали автобіографізм. Попри наполегливі заперечення автора й спроби акцентувати на фікційній природі свого твору навколо його імені розгортається публічний скандал і поширюються звинувачення в цинізмі, ксенофобії, жінконенависництві. Все це дуже нагадує історію з романом самого Філіпа Рота «Випадок Портного», в якому більшість читачів та інтерпретаторів побачили конфлікт письменника із єврейським середовищем, бажання висміяти його i звільнитися від традиції, що сформувала його особистість. Подібного до автора роману «Звільнений Цукерман», автор «Карновскі» намагається довести принципову відмінність між реальністю і художнім вимислом, письменником i його персонажами. Його позиція полягає в тому, що автобіографічний первінь неминуче присутній у книжках будь-якого письменника, навіть коли він сам це заперечує. Натомість письменник послідовно відстоює ідею автономності життя і мистецтва. Отож у романі «Звільнений Цукерман» Ф. Рот художньо трансформує ситуацію власної творчої біографії, водночас створюючи оригінальну трирівневу метатекстуальну модель стосунків мистецтва і дійсності.

Щодо третьої ознаки постмодернізму (проблематизація людини як предмета літератури і заміна його самою літературою), то у випадку Ф. Рота вона нібито легко може бути спростована, адже персонажі письменника завжди $€$ «живими людьми», із складними й неоднозначними характерами. Однак і тут не все так просто, оскільки в їхні життєписи обов'язково проникає «література» й почасти читач розводить руками - де ж реальна людина, а де вигадана. Так, у 
романі «Контржиття» (The Counterlife) [10] його протагоніст, той самий письменник Натан Цукерман, що діє і ніби змагається з реальністю й у інших творах автора, описує історію свого брата Генрі. Останній переїздить із американського штату Нью-Джерсі до Ізраїлю, де починає зовсім нове, «контржиття», згідно 3 назвою твору. Натан у пошуках свого брата намагається з'ясувати, що ж відбувається 3 ним і 3 самою реальністю «історичної батьківщини», повної непереборних контрастів і суперечностей. Особливо яскраво це ілюструє зустріч письменника 3 палким прихильником його творчості, колишнім американцем, а тепер студентом юдейського релігійного навчального закладу Джіммі Бен-Джозефом, який не лише не розуміє сутності книг Цукермана, а до абсурду перевертає їх зміст, як і реальність сучасного Ізраїлю. Те саме бачить Натан і в житті свого брата Генрі, який обрав собі нове ім'я - Ханок.

Події роману, крім США та Ізраїлю, охоплюють також і Європу, зокрема Англію, графство Глостершир, куди Генрі знову переїздить, щоб розпочати ще одне «контржиття». Всі представлені в романі різновиди «іншого життя« раптово вибухають новими змістами, коли пізніше у текст вплітаються листи й нотатки Натана Цукермана, з яких стає зрозумілим, що описані події життя Генрі існували лише в уяві письменника, тобто «реальність» виявилася авторською фантазією, ілюзією справжнього життя. Показово, що сам Філіп Рот назвав «Контржиття» романом, який «підриває власні вигадані постулати» [7, p. 11].

У зв'язку з таким варіантом проблематизації реальності і людиниперсонажа літературного твору в «Контржитті» можна говорити й про «тотальну іронію і гру» - наступну ознаку постмодернізму. Філіп Рот продовжує грати з сюжетом, наративом, читачем і в наступних своїх творах. Так, у романі «Факти: Автобіографія романіста» він пише вже від першої особи Філіпа Рота й нібито послуговується лише документальними фактами, але потім усе перевертається догори дригом, коли автор-наратор Філіп Рот включає у текст свій лист до Натана Цукермана й отримує від нього (вигаданого персонажа його попередніх творів!) відповідь, яка також стає частиною сюжету твору.

Щодо інтертекстуальності у творах Філіпа Рота, то про цю особливість його поетики є чимало студій (див., зокрема, детальний аналіз античного інтертексту в романі [4].

Ще одну ознаку постмодернізму - радикальний перегляд традиційних жанрово-стильових конвенцій - можна продемонструвати фактично на прикладі будь-якого твору Філіпа Рота (взірцем можуть бути згадані вище «Факти..»), але особливо яскраво вона виявляється в романі «Грудь» (The Breast). Метаморфоза, що відбувається 3 персонажем-наратором твору, професором літератури Дейвідом Кепешем (перетворення його на велику жіночу грудь), відразу заявлена ним як підозра на літературний вплив Миколи Гоголя і Франца Кафки, що спричинив божевілля: «Я вважав, це від літератури. Книжки, які я вивчав зі студентами $<\ldots>$ Кожний рік я розповідав про Гоголя і Кафку, про «Ніс» і «Перевтіення» [8, р. 60]. Акцентована інтертекстуальність у 
даному випадку має наслідком контамінацію психологічного роману й пародійного фарсу, своєрідного фізіологічного нарису й університетського роману, тобто створення постмодерністського жанрово-стильового пастишу.

Таким чином, романи Філіпа Рота очевидно суголосні постмодерністській парадигмі. Водночас його жодною мірою не можна віднести до апологетів i пристрасних послідовників постмодернізму. Попри численні експерименти 3 реальністю, кращі його твори (як-от «Людське тавро») говорять про небайдужість до людського страждання, засвідчують загальну еволюцію постмодерністської літератури до «воскресіння суб’єкта», відновлення повноцінного людського характеру як письменницької мети замість концептуалізації розщепленого «Я» і дегуманізованої особистості. «Епістемологічна невизначеність» авторської позиції зберігає актуальність, «суб'єкт» залишається незавершеним (в першу чергу для самого себе), відчуття невиправності існування, неможливості осягнення глибинних меж людської сутності не знімається, але набуває ознак екзистенціального запитування.

\section{ЛІТЕРАТУРА}

1. Encyclopedia of Postmodernism / ed. by Victor E. Taylor, Charles E. Winquist. Routledge, London \& New York, 2001. 408 p.

2. Карасик О. Б. Мотив превращения у Николая Гоголя и Филипа Рота: от реализма к постмодернизму. Филология и культура. Philology and Culture. 2016. № 1(43). С. 218-222.

3. Кеба О. В. «Людське тавро» Філіпа Рота як варіант неореалістичного роману в сучасній американській літературі. Актуальні питання та проблеми розвитку сучасної мови та літератури: міжнар. науково-практич. конф., м. Одеса, 19-20 серпня 2016 р. Одеса: Південноукраїнська організація «Центр філологічних досліджень», 2016. С. 13-15.

4. Кеба О. В. Міфологічний інтертекст у романі Філіпа Рота «Людське тавро». Міф $y$ художній свідомості та культурі XX cm. (II Мішуковські читання) : матеріали МНК, м. Херсон, 13-14 жовтня 2017 р. Херсон : Вид. дім «Гельветика», 2017. С. 31-35.

5. Kellogg C. 61 essential postmodern reads: an annotated list. URL: https://latimesblogs.latimes.com/jacketcopy/2009/07/the-mostly-complete-annotated-and-essentialpostmodern-reading-list.html (дата звернення: 03.02.2020).

6. Masiero, P. Philip Roth and the Zuckerman Books : The Making of a Storyworld. NJ : Amherst, Cambria Press, 2011. 276 p.

7. Reading Philip Roth / ed. by Asher Z. Milbauer and Donald G. Watson. New York : St. Martin's Press, 1988. XIV, 205 p.

8. Roth Ph. The Breast. N.Y. : Vintage Books. A Division of Random House, Inc., 1995. 89 p.

9. Roth Ph. Zuckerman Unbound. N.Y. : Vintage Books. A Division of Random House, Inc., 1995. $225 \mathrm{p}$.

10. Roth Ph. Counterlife. N.Y. : Vintage Books. A Division of Random House, Inc., 1996. 324 p.

11. Roth, Philip. The Human Stain. URL : http://flibusta.is/b/215222/read (дата звернення: 03.02.2020).

12. Затонский Д. В. Модернизм и постмодернизм. Харьков : Фолио; Москва : ООО «Издательство АСТ», 2000. 256 с.

\section{REFERENCES}

1. Encyclopedia of Postmodernism (2001), ed. by Victor E. Taylor, Charles E. Winquist. Routledge, London \& New York, 408 p. (in English).

2. Karasik, O. (2016), "The Motif of Transformation in Nikolai Gogol's and Philip Roth's Fiction: from Realism to Postmodernism" ["Motiv Prevrashcenia u Nikolaia Gogolia i Filipa Rota: ot realizma k postmodernizmu], Philology and Culture. No 1(43), pp. 218-222. (in Russian).

3. Keba, O. (2016), “The Human Stain' by Ph. Roth as a variant of neo-realistic novel in modern 
american literature" [“"Liudske tavro' Filipa Rota yak variant neorealistychnogo romanu v suchasnii amerykanskii literaturi"], Aktualni pytannia ta problem rozvytku suchasnji movy ta literatury, Centr filologichnyh doslidzhen, Odessa, pp. 13-15. (in Ukrainian).

4. Keba, O. (2017), "Mythological intertext in 'The Human Stain' by Ph. Roth" ["Mifologichnyi intertekst u romani Filipa Rota 'Liudske tavro'"], Mif u hudozhnii svidomosti ta kulturi XX st., Vyd. dim "Helvetyka", Kherson, pp. 31-35. (in Ukrainian).

5. Kellogg, C. (2009), "61 essential postmodern reads: an annotated list", available at: https://latimesblogs.latimes.com/jacketcopy/2009/07/the-mostly-complete-annotated-and-essentialpostmodern-reading-list.html (in English).

6. Masiero, P. (2011), Philip Roth and the Zuckerman Books: The Making of a Storyworld, Amherst, NJ. Cambria Press, 276 p. (in English).

7. Reading Philip Roth. (1998), ed. by Asher Z. Milbauer and Donald G. Watson. St. Martin's Press, N.Y., XIV, 205 p. (in English).

8. Roth Ph. (1995), The Breast, Vintage Books, A Division of Random House, Inc., N.Y. 89 p. (in English).

9. Roth Ph. (1995), Zuckerman Unbound, Vintage Books, A Division of Random House, Inc., N.Y., 225 p. (in English).

10. Roth Ph. (1996), Counterlife, Vintage Books, A Division of Random House, Inc., N.Y., 324 p. (in English).

11. Roth, Ph. (2000), “The Human Stain”, available at: http://flibusta.is/b/215222/read (in English). 12. Zatonskii, D. (2000), Modernism and Postmodernism [Modernizm i postmodernizm], Folio, Kharkov; AST, Moscow, 256 p. (in Russian).

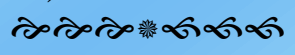

